\title{
Modelling Soil Water Dynamics under Rainfed Agriculture to Mitigate Climate Change
}

\author{
Mukhtar Ahmed ${ }^{1}$, Arvind H. Hirani ${ }^{2}$, Muhammad Asif ${ }^{3} \&$ Muhammad Sajad $^{4}$ \\ ${ }^{1}$ Department of Agronomy, PMAS Arid Agriculture University Rawalpindi, Pakistan \\ ${ }^{2}$ Department of Plant Science, University of Manitoba, Winnipeg, Canada \\ ${ }^{3}$ Department of Agricultural, Food and Nutritional Science, University of Alberta, Edmonton, AB T6G 2P5, \\ Canada \\ ${ }^{4}$ Department of Plant Breeding and Genetics, University College of Agriculture \& Environmental Sciences, The \\ Islamia University of Bahawalpur, Punjab, Pakistan \\ Correspondence: Mukhtar Ahmed, Department of Agronomy, PMAS Arid Agriculture University Rawalpindi, \\ Pakistan. Tel: 92-51-929-0757. E-mail: ahmadmukhtar@uaar.edu.pk
}

Received: December 28, 2012 Accepted: January 16, 2013 Online Published: February 5, 2013

doi:10.5539/jas.v5n3p90 URL: http://dx.doi.org/10.5539/jas.v5n3p90

\begin{abstract}
The model performance to simulate soil water dynamics was evaluated by comparing the predicted soil water content values with calculated soil water at different phenological stages of wheat and total soil available water using neutron probe. The pre-sowing soil water $(\mathrm{mm})$ in this study varied from 40 to $50 \mathrm{~mm}$ in loam and sandy clay soil of Islamabad and Chakwal, respectively. When soil water is $>50 \mathrm{~mm}$, its effect on crop establishment is dependent on amount and temporal distribution of rainfall. Plant available soil water seems to be the most important factor if rainfall occurs between sowing and floral initiation period as happened during 2008-09 in the present study. The dynamics of soil water from emergence to maturity represented here as total soil water that remained maximum at earlier plant stages especially when crop roots were established and utilized soil water effectively that resulted in the lowest level of water at maturity which can be due to the evapotranspiration. The results depicted that the soil water distribution pattern mainly depends on soil properties and if sowing methodologies are resilient with available soil water then crop stand will be good and crop uses water much effectively. The results also depicted that when soil water is at drain upper limit (DUL) and the crop sown at proper time along with least soil evaporation, the soil water can be more easily taken up by the plant roots. Furthermore, the simulated soil water by the model was in close agreement with actual data. The validation skill scores like $\mathrm{R}^{2}$ confirmed the actuality of the model, therefore, dynamic model like Agricultural Production System Simulator (APSIM) could be used to describe the distribution of rainwater into different components like infiltration, runoff and drainage, and it can be used as a decision support tool for accurate management of different cultural operations for sustainable atmosphere-soil-plant (ASP) system.
\end{abstract}

Keywords: APSIM, evapotranspiration, neutron probe, plant available water, rainfed, soil water dynamics

\section{Introduction}

Weather is one of the major factors that affect the reserves of water in the soil. The dry weather leads to severe drought that causes severe yield and quality losses in agricultural crops. The water dynamics in the atmosphere-soil-plant (ASP) system represent the capacity of soil as a water reservoir to have depletion and replenishment for successful crop production (Ritchie, 1981). The triangle of ASP determines the available water to the crop at the critical growth stages. Since, water is the most common and important resource on earth therefore, studying its dynamics in ASP system is important for its management. The most important source of water to the plant is soil, where water get recharge and is mainly dependent on rainwater. The movement of water in the soil by dynamic model like Agricultural Production System Simulator (APSIM) can be represented by two approaches, cascading bucket and Richards's equation. Both these approaches maintain a balance of water like a closed system and dynamics of water in closed system can be represented by following equation.

$$
\mathrm{R}+\mathrm{I}=\Delta \mathrm{SW}+\mathrm{Et}+\mathrm{Es}+\mathrm{RO}+\mathrm{D}
$$


Where $\mathrm{R}=$ rainfall, $\mathrm{I}=$ infiltration, $\Delta \mathrm{SW}=$ change in soil water, $\mathrm{Et}=$ evapotranspiration, Es = surface evaporation, $\mathrm{RO}=$ runoff and $\mathrm{D}=$ drainage. Similarly, flux of water in the ASP system is represented diagrammatically in Figure 1 (Agricultural Production Systems Research Unit, APSRU, Toowoomba).

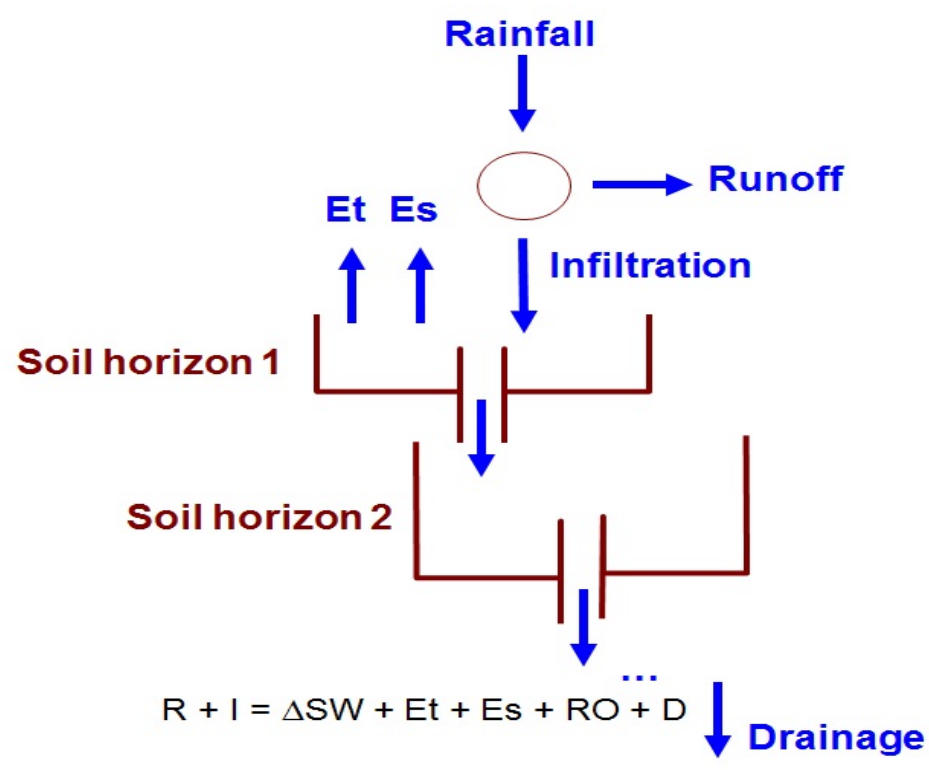

Figure 1. Schematic diagram of soil water dynamics

Source: http://www.apsim.info/Wiki/SoilWat.ashx

Climatic resilience is the ability of a system to show stability against climatic stresses. Resilience of soil and crop is the opposite of vulnerability where a soil and crop develops the capacity to adapt to the environmental stresses and disturbances. The soil having flexibility in their water and nutrients recycling is considered to be more resilient to particular systems. Climate vulnerability threatens Pakistan's food production systems, thus life of at least $70 \%$ people will be affected significantly because they are associated with agricultural production in the one way or other. The rainfed areas of Pakistan are more exposed to the effects of climatic variability because entire cropping system of rainfed areas is solely dependent on rainfall which determines soil water available to the plants. Building of resilient system is therefore essential for the rainfed areas of Pakistan to address the issue of available water at critical plant growth developmental stages. High variability of rainfall and increased temperature has been observed in rainfed areas in the recent decade that has reduced soil productivity to a greater extent. Floods, drought, terminal heat stress and frost are the main climatic events of the decade affecting crop-soil interactions in the rainfed areas (Table 1). These events are related to climatic drivers like sea surface temperatures (SSTs) and pressure like Indian Ocean dipole (IOD).

Summer rainfall variability in the subcontinent is mainly dependent on El Nino and IOD that affect soil water dynamics significantly. Therefore, use of crop simulation models linked with the improved knowledge of seasonal climate forecasting using ENSO (El Niño Southern Oscillation) and SOI (Southern Oscillation Index) offer better risk management against climate variability. Since, the negative and positive phases of SOI affect the rainfall occurrence and distribution patterns at specific time periods over the locations, therefore, if the phase is negative with two months lag period, then there is a possibility of less rain after two months and vice versa (Stone $\&$ Auliciems, 1992).

The crop production activities also depend on drainage systems and hydrological parameters of the country and it is also influenced by the rainfall which is received during monsoon and these monsoon rains has a significant impact on the economy of the country. Therefore, agricultural planning must need to incorporate the soil water dynamics which is mainly dependent on rainfall. The monsoon season contributes maximum to the average annual rainfall in the country and is also linked with occurrence of flood like in 2010 causing extensive damage to the agricultural crops and land. Therefore, there is dire need to use forecasting system to integrate with models to design an adaptation and mitigation strategy for future. In the rainfed region of Pakistan, dry spell is a common 
feature before and during the crop growing season particularly for wheat which is main staple food and grown on an area of 8805 thousand hectares during 2010-11 (Economic Survey of Pakistan, 2011). Therefore, the development of soil water dynamics model and provision of suitable information to the farming community especially regarding planting time based on geographic as well as environmental factors is a prerequisite to maximize agricultural productivity on sustainable basis.

Table 1. Effects of climate events on wheat production in rainfed area

\begin{tabular}{|c|c|c|c|}
\hline Cropping Year & Climate Events & Yield (kg/ha) & $\%$ change \\
\hline $1999-00$ & Drought (Weak La- Nina) & 1319 & -25 \\
\hline 2000-01 & $\begin{array}{l}\text { Drought }+ \text { Terminal heat stress } \\
\text { (Non El-Nino Drought) }\end{array}$ & 534 & -70 \\
\hline 2001-02 & $\begin{array}{l}\text { Drought }+ \text { Terminal heat stress } \\
\text { (Non El-Nino Drought) }\end{array}$ & 717 & -59 \\
\hline 2002-03 & Drought (Moderate El-Nino) & 1310 & -25 \\
\hline 2003-04 & $\begin{array}{l}\text { Terminal heat stress } \\
\text { (Non El-Nino Drought) }\end{array}$ & 1321 & -25 \\
\hline 2004-05 & (Week El-Nino) & 1730 & -1 \\
\hline $2005-06$ & $\begin{array}{l}\text { Terminal heat stress } \\
\text { (Non El-Nino Drought) }\end{array}$ & 1354 & -23 \\
\hline 2006-07 & $\begin{array}{l}\text { Bumper Crop Year } \\
\text { (Moderate El-Nino) }\end{array}$ & 1755 & $=$ \\
\hline 2007-08 & $\begin{array}{l}\text { Frost }+ \text { Terminal heat stress } \\
\text { (Moderate La-Nina) }\end{array}$ & 1205 & -31 \\
\hline 2008-09 & Non El-Nino year & 1465 & 017 \\
\hline $2009-10$ & Drought (Moderate El-Nino) & 945 & -46 \\
\hline 2010-11 & Strong Lanina & 1760 & +1 \\
\hline 2011-12 & $\begin{array}{l}\text { Terminal heat stress } \\
\text { (Moderate El-Nina) }\end{array}$ & 1200 & -31 \\
\hline
\end{tabular}

The variability in climate change is affecting the overall agricultural production. The Inter-Governmental Panel on Climate Change has indicated that rising temperatures, drought, floods, desertification and weather extremes will severely affect agriculture, especially in the developing world. The increased population and climate change threatens food security worldwide. Therefore, to ensure food security and to mitigate the negative effects of climate changes, adaptation of modelling approach to capture single mole of water is highly desirable. Similarly, to cope with the growing threat of water stress and heat, it's important to consider crop with high drought tolerance ability along with high water use efficiency. The use of modelling tools has proven their efficiency in agriculture against vulnerable climatic conditions (Dettori et al., 2011). Plants get water from soil through transpirational pull to maintain their life. Water is essential substrate for plant biochemical reactions and also source of nutrients for plant growth. The soil internal environment influences the movement of water within the root zone. There is a broad range soil water contents for sufficient water and nutrient transport to the plant. Water dynamics include rainfall, drainage from root zone, runoff and evapotranspiration (Figure 2).

Climatologically, most parts of Pakistan have significant spatiotemporal variability representing arid to semi-arid area of the world. Monsoon contributes 59\% of annual rainfall (Farooqi et al., 2006). Geological factors irrespective of meteorological factors (rainfall amount and intensity) have a great influence on variation in soil water dynamics because of heterogeneity in rainfall redistribution and evapotranspiration processes (Liang et al., 2007). Similarly, global climate changes like drought and floods are affecting the available soil water and have severed effects in the Northern areas of the world. (Meehl \& Tebaldi, 2004; Schar et al., 2004). 
Resilience of rainfed agriculture with drought and dry spell is fundamental for water security. Resilience is the ability of system to remain sustainable and flexible for longer period of time and to recover from unfavorable conditions. Water resilience in rainfed aims at securing water availability for longer period of time especially under persistent drought by integrating models with climatic drivers. The concept of green water which supplies $60-70 \%$ of grain foods in the world (rainfall water) and blue water (runoff water) was introduced by Falkenmark (2003). Management of green water is therefore important for sustainability of the system.

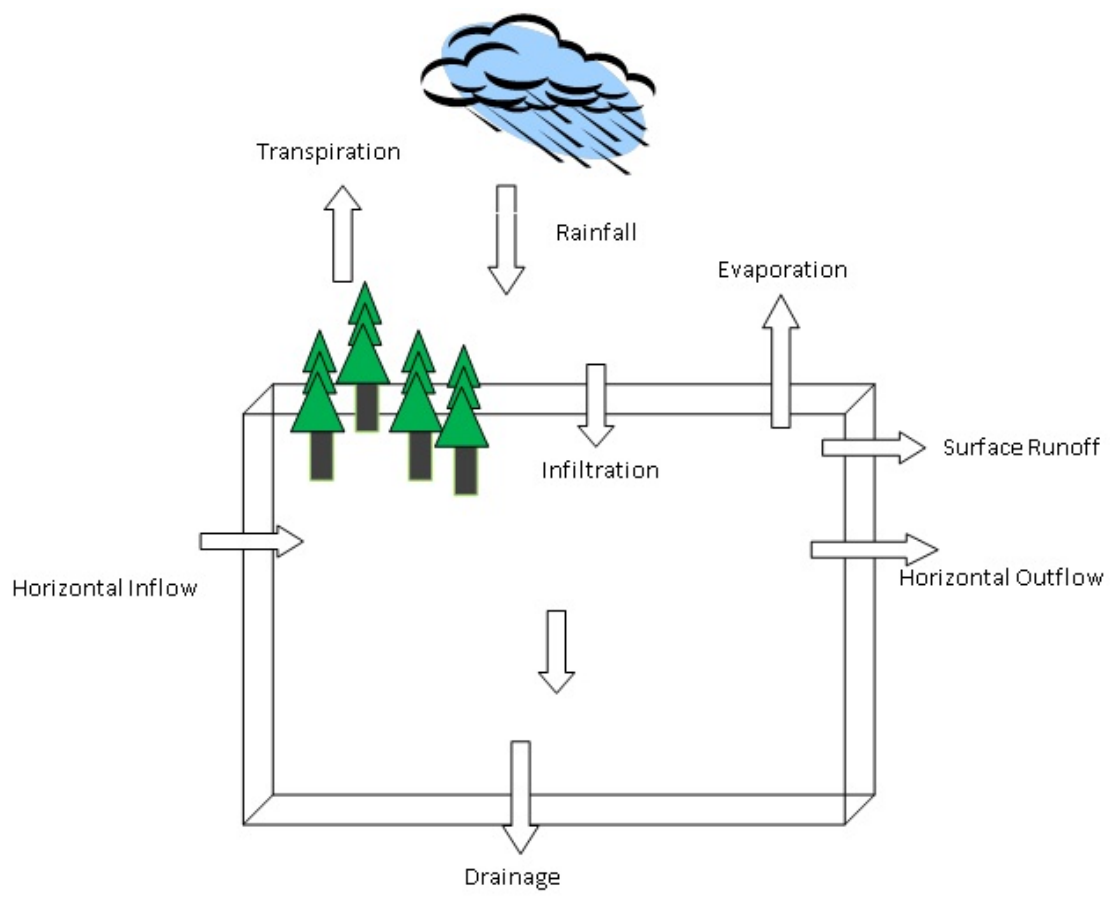

Figure 2. Schematic diagram of soil water dynamics

Movement and distribution of water in soils takes place through pores; association and distribution of pores are of dynamic significance for the transport and retention of water in the soil. Crops use this water for evapotranspiration and aquifers are fed by this water as well. In general, volumetric depiction of soil porosity is not enough for explaining soil water dynamics. The earth's climate has been fluctuating constantly over millennia but the last two centuries have observed the expansion of the greenhouse problem, which threatens to change climate in an extraordinary manner (Farooqi et al., 2005). In most part of Pakistan, the quality of available ground water is not suitable for sustainable crop production and soil health (Ali et al., 2009). The productivity of rainfed ecosystem totally depends on rainwater fluxes and if it is not upto the required limit, it might lead to drought. Nowadays, groundwater quality is a main concern for sustainable crop production.

The proportion of total rainfall that becomes runoff during a storm event represents the runoff coefficient (Longobardi et al., 2003). The runoff ratio changeability is also well documented in the literature, even though there is no clear conclusion about what factors govern this variability (Wainwright et al., 2002). The conversion of rainfall into different components like infiltration, runoff, drainage and percolation is not a linear process. However, change of rainwater into plant available water depends on the physical health of soil. Similarly, soil water available to the crop in the rhizoshere is important for maintenance of all components of hydrological cycle. The soil water in the rhizosphere regulates the division of rainfall into infiltration, storage in the rhizosphere and into deeper zone of soil through percolation. The availability of soil water to the crop and its evapotranspiration demand might be fulfilled by the available soil water in the root zone for sustainable agricultural production. The measurement of soil water is not monitored on daily basis same like climatic variables because of its high spatiotemporal variability (Yamaguchi \& Shinoda, 2002). Soil water could be however measured at two extreme scales like scale of square meter with gravimetric method (point scale) and by the use of remote sensing techniques called pixel size method. Radiation sources are another method being used nowadays to measure soil water. This includes the use of neutron and gamma probe. These probes need to be calibrated according to specific soil (Akhtar \& Qureshi, 1996). 
The influence of climatic variability on the agricultural system might be simulated for future by the use of climate models. Models are of extreme importance in scientific systems (Frigg \& Hartman, 2006). A model is a schematic demonstration of the ideology of a system or a set of equations, which shows the performance of a system. Also, a model is "a demonstration of an object, structure or proposal in some form other than that of the individual itself". Models are used to describe and improve the behaviour of a system in real and simple form and this simplicity results in the effectiveness of models as it presents the complete explanation of problem. Building, testing, comparing and revising models need a great deal of time of scientists and introduction, application and interpretation of these imperative tools needs much general space (Frigg \& Hartman, 2006).

The reaction which occurs within the plants and the interaction of plants with environment is represented in the agricultural models. The agricultural models are the clear picture of reality as it is very difficult and impossible to represent the complete system in arithmetical expressions due to incomplete status of present knowledge and complicacy of the system. In the agricultural sector, universal models do not exist as in the fields of engineering and physics. Complexity level is adopted according to the principle of the model and for different systems; different models can be used. The models might be paired with field data by considering environmental variables. Therefore models are real source of knowledge under different circumstances like soil water managements, crop sequestration and tillage practices. The dynamic model APSIM (Agricultural Production Systems Simulator) is a software system that allows models of crops, soil water, nutrients and erosion to be flexibly configured to simulate diverse production systems (McCown et al., 1996). APSIM is a dynamic versatile model which can simulate crop and farming systems operations with good precision to mimic climatic risks and sustain optimum yield potential. It has vast applications like decision making, forecasting and risk evaluation for sustainable management (Keating et al., 2003). It can simulate the soil and plant dynamics along with their interactions with managements under wide spectrum of farming operations (Wang et al., 2002). It has been parameterized and validated to explain the impacts of climatic variation on wheat yield and to enhance climate forecasting utilizations for rainfed agriculture. Furthermore, this dynamic model has been used to forecast rainfall under rainfed ecosystem and it has been patched with R. Generalised Additive Model (GAM), that has been used to establish lagged relationship with climatic predictors and rainfall. The GAM model then used to forecast above and below median rainfall for the study sites. Furthermore, the forecast skill has been assessed using cross-validated skill scores. The results led to conclusion that APSIM model is appropriate to simulate wheat yield and can be further used for scenario analysis under changing climatic conditions (Ahmed et al., 2010; Ahmed, 2012).

The present study was therefore conducted with the objectives (a) to understand soil water dynamism and its relation with climate change under variable climatic conditions of Pothwar region, (b) to parameterize and evaluate the APSIM under variable local environmental conditions and (c) to enhance understanding about the resilience of soil under rainfed conditions using APSIM.

\section{Material and Methods}

\subsection{Experiment Sites}

The experimental sites of rainfed ecosystem included in the experiment were Islamabad $\left(33^{\circ} 40^{\prime} \mathrm{N}, 73^{\circ} 10^{\prime} \mathrm{E}, 508 \mathrm{~m}\right.$ a.s.l.) and Chakwal $\left(32^{\circ} 56^{\prime} \mathrm{N}, 72^{\circ} 52^{\prime} \mathrm{E}, 513 \mathrm{~m}\right.$ a.s.l.). The daily rainfall data was collected from the Meteorology Department of Pakistan (http://www.pakmet.com.pk/). The sites have subtropical thermal climate with summer-dominant rainfall (Fischer et al., 2002). The Islamabad is located in the high rainfall zone and has dry sub-humid climate with $>1000 \mathrm{~mm}$ average annual rainfall and an average annual temperature of $21.3^{\circ} \mathrm{C}$. The semi-arid site Chakwal $(600 \mathrm{~mm}$ average annual rainfall) is situated in the medium rainfall zone, and has an average annual temperature of $22.4^{\circ} \mathrm{C}$. Rainfall during the wheat growing season (November to April) is highly variable, with the seasonal variability being greater than the annual. These two sites have fitted and calibrated neutron probe which were used to take soil water data at fifteen day intervals. The principle of neutron probe involves bombardment of fast moving neutrons into moist soil which can slow down the neutron resulting in the generation of cloud of slow neutron around the source. The density of slow neutron produced is directly proportional to the content of water which is present in the soil. Therefore, by measuring density of slow neutrons we can measure present water content of soil. The method is fast, less expensive and accurate but needs calibration for good results (Akhtar \& Qureshi, 1995). Similarly, neutron probe calibration equation developed and presented by earlier studies was used to measure volumetric soil water contents (Akhtar \& Qureshi, 1996).

\subsection{Soil Physiochemical Characteristics}

The soils of the study sites are of varying nature. Islamabad has loamy soil, whereas soil of Chakwal site is sandy clay loam. The detailed physiochemical properties of the study sites are presented in Tables 2 and 3. 
Table 2. Physiochemical characteristics of soil at Islamabad during 2008-09 and 2009-10

\begin{tabular}{|c|c|c|c|c|c|c|c|}
\hline $\begin{array}{l}\text { Determinations } \\
(2008-09)\end{array}$ & Units & $0-15$ & $15-30$ & $30-45$ & $45-60$ & $60-75$ & $75-90$ \\
\hline$\overline{\mathrm{pH}}$ & $1: 1$ & 7.5 & 7.6 & 8.3 & 8.2 & 8.4 & 8.4 \\
\hline EC & $\mathrm{dSm}^{-1}$ & 0.24 & 0.2 & 0.21 & 0.21 & 0.22 & 0.21 \\
\hline Nitrogen & $\%$ & 0.04 & 0.04 & 0.03 & 0.030 & 0.02 & 0.02 \\
\hline Nitrate-N & $\mathrm{mg} \mathrm{kg}^{-1}$ & 7.86 & 7.28 & 6.50 & 6.20 & 5.24 & 5.00 \\
\hline AV.P & $\mathrm{mg} \mathrm{kg}^{-1}$ & 3.64 & 3.39 & 3.90 & 3.72 & 2.72 & 2.54 \\
\hline $\mathrm{K}$ & $\mathrm{mg} \mathrm{kg}^{-1}$ & 160 & 180 & 210 & 220 & 210 & 240 \\
\hline Organic Carbon & $\%$ & 0.91 & 0.87 & 0.63 & 0.6 & 0.44 & 0.41 \\
\hline Silt & $\%$ & 33 & 33 & 33 & 33 & 33 & 33 \\
\hline Sand & $\%$ & 35 & 35 & 35 & 35 & 35 & 35 \\
\hline Clay & $\%$ & 32 & 33 & 34 & 35 & 35 & 35 \\
\hline Texture & & Loam & Loam & Loam & Loam & Loam & Loam \\
\hline B.Density & $\mathrm{gcm}^{-3}$ & 1.24 & 1.42 & 1.46 & 1.52 & 1.59 & 1.65 \\
\hline SLL & $\mathrm{mmmm}^{-1}$ & 0.07 & 0.09 & 0.09 & 0.09 & 0.09 & 0.09 \\
\hline SDUL & $\mathrm{mmmm}^{-1}$ & 0.34 & 0.24 & 0.25 & 0.26 & 0.23 & 0.23 \\
\hline Saturated SW & $\mathrm{mmmm}^{-1}$ & 0.48 & 0.40 & 0.38 & 0.36 & 0.33 & 0.31 \\
\hline Soil Albedo & 0.13 & & & & & & \\
\hline $\begin{array}{l}\text { Determinations } \\
(2009-10)\end{array}$ & Units & $0-15$ & $15-30$ & $30-45$ & $45-60$ & $60-75$ & $75-90$ \\
\hline $\mathrm{pH}$ & & 7.4 & 7.5 & 7.9 & 8.2 & 8.4 & 8.4 \\
\hline $\mathrm{EC}$ & $\mathrm{dSm}^{-1}$ & 0.23 & 0.2 & 0.2 & 0.21 & 0.22 & 0.21 \\
\hline Nitrogen & $\%$ & 0.039 & 0.037 & 0.027 & 0.026 & 0.019 & 0.017 \\
\hline Nitrate-N & $\mathrm{mg} \mathrm{kg}^{-1}$ & 6.4 & 5.9 & 5.3 & 5.0 & 4.2 & 4.1 \\
\hline AV.P & $\mathrm{mg} \mathrm{kg}^{-1}$ & 3.1 & 2.9 & 3.3 & 3.2 & 2.3 & 2.2 \\
\hline $\mathrm{K}$ & $\mathrm{mg} \mathrm{kg}^{-1}$ & 120 & 135 & 159 & 165 & 158 & 180 \\
\hline Organic Carbon & $\%$ & 0.72 & 0.69 & 0.50 & 0.47 & 0.35 & 0.32 \\
\hline Silt & $\%$ & 33 & 33 & 33 & 33 & 33 & 33 \\
\hline Sand & $\%$ & 35 & 35 & 35 & 35 & 35 & 35 \\
\hline Clay & $\%$ & 32 & 32 & 32 & 32 & 32 & 32 \\
\hline Texture & & loam & Loam & loam & loam & loam & Loam \\
\hline B.Density & $\mathrm{gcm}^{-3}$ & 1.22 & 1.40 & 1.44 & 1.50 & 1.57 & 1.63 \\
\hline SLL & $\mathrm{mmmm}^{-1}$ & 0.07 & 0.09 & 0.09 & 0.09 & 0.09 & 0.09 \\
\hline SDUL & $\mathrm{mmmm}^{-1}$ & 0.34 & 0.24 & 0.25 & 0.26 & 0.23 & 0.23 \\
\hline Saturated SW & $\mathrm{mmmm}^{-1}$ & 0.46 & 0.39 & 0.38 & 0.36 & 0.33 & 0.31 \\
\hline Soil Albedo & 0.13 & & & & & & \\
\hline
\end{tabular}


Table 3. Physiochemical characteristics of soil at Chakwal during 2008-09 and 2009-10

\begin{tabular}{|c|c|c|c|c|c|c|c|}
\hline $\begin{array}{l}\text { Determinations } \\
(2008-09)\end{array}$ & Units & $0-15$ & $15-30$ & $30-45$ & $45-60$ & $60-75$ & $75-90$ \\
\hline $\mathrm{pH}$ & $1: 1$ & 8.1 & 8.1 & 8.6 & 8.8 & 8.5 & 8.5 \\
\hline EC & $\mathrm{dSm}^{-1}$ & 0.32 & 0.3 & 0.34 & 0.26 & 0.32 & 0.28 \\
\hline Nitrogen & $\%$ & 0.04 & 0.03 & 0.02 & 0.02 & 0.02 & 0.02 \\
\hline Nitrate-N & $\mathrm{mg} \mathrm{kg}^{-1}$ & 3.04 & 2.83 & 3.26 & 3.10 & 2.27 & 2.12 \\
\hline AV.P & $\mathrm{mg} \mathrm{kg}^{-1}$ & 2.80 & 2.61 & 3.00 & 2.86 & 2.10 & 1.96 \\
\hline K & $\mathrm{mg} \mathrm{kg}^{-1}$ & 114 & 129 & 150 & 157 & 150 & 171 \\
\hline Organic Carbon & $\%$ & 0.72 & 0.65 & 0.47 & 0.45 & 0.33 & 0.31 \\
\hline Silt & $\%$ & 23 & 22 & 21 & 20 & 20 & 20 \\
\hline Sand & $\%$ & 56 & 56 & 56 & 56 & 56 & 56 \\
\hline Clay & $\%$ & 21 & 22 & 23 & 24 & 25 & 26 \\
\hline Texture & & $\begin{array}{l}\text { Sandy } \\
\text { clay } \\
\text { loam }\end{array}$ & $\begin{array}{l}\text { Sandy } \\
\text { clay } \\
\text { loam }\end{array}$ & $\begin{array}{l}\text { Sandy } \\
\text { clay } \\
\text { loam }\end{array}$ & $\begin{array}{l}\text { Sandy } \\
\text { clay loam }\end{array}$ & $\begin{array}{l}\text { Sandy } \\
\text { clay loam }\end{array}$ & $\begin{array}{l}\text { Sandy } \\
\text { clay } \\
\text { loam }\end{array}$ \\
\hline B.Density & $\mathrm{gcm}^{-3}$ & 1.29 & 1.45 & 1.55 & 1.65 & 1.7 & 1.75 \\
\hline SLL & $\mathrm{mmmm}^{-1}$ & 0.061 & 0.080 & 0.080 & 0.080 & 0.083 & 0.083 \\
\hline SDUL & $\mathrm{mmmm}^{-1}$ & 0.25 & 0.18 & 0.19 & 0.19 & 0.18 & 0.17 \\
\hline Saturated SW & $\mathrm{mmmm}^{-1}$ & 0.48 & 0.38 & 0.35 & 0.31 & 0.29 & 0.27 \\
\hline Soil Albedo & 0.14 & & & & & & \\
\hline $\begin{array}{l}\text { Determinations } \\
(2009-10)\end{array}$ & Units & $0-15$ & $15-30$ & $30-45$ & $45-60$ & $60-75$ & $75-90$ \\
\hline $\mathrm{pH}$ & $1: 1$ & 7.9 & 7.7 & 7.8 & 7.8 & 7.8 & 7.9 \\
\hline EC & $\mathrm{dSm}^{-1}$ & 0.28 & 0.3 & 0.31 & 0.31 & 0.3 & 0.29 \\
\hline Nitrogen & $\%$ & 0.03 & 0.03 & 0.02 & 0.02 & 0.01 & 0.01 \\
\hline Nitrate-N & $\mathrm{mg} \mathrm{Kg}^{-1}$ & 2.58 & 2.40 & 2.77 & 2.64 & 1.93 & 1.80 \\
\hline AV.P & $\mathrm{mg} \mathrm{kg}^{-1}$ & 2.38 & 2.22 & 2.55 & 2.43 & 1.78 & 1.66 \\
\hline K & $\mathrm{mg} \mathrm{kg}^{-1}$ & 109 & 122 & 143 & 149 & 143 & 163 \\
\hline Organic Carbon & $\%$ & 0.68 & 0.62 & 0.45 & 0.43 & 0.31 & 0.29 \\
\hline Silt & $\%$ & 23 & 22 & 21 & 20 & 20 & 20 \\
\hline Sand & $\%$ & 56 & 56 & 56 & 56 & 56 & 56 \\
\hline Clay & $\%$ & 21 & 22 & 23 & 24 & 25 & 26 \\
\hline Texture & & $\begin{array}{l}\text { Sandy } \\
\text { clay } \\
\text { loam }\end{array}$ & $\begin{array}{l}\text { Sandy } \\
\text { clay } \\
\text { loam }\end{array}$ & $\begin{array}{l}\text { Sandy } \\
\text { clay } \\
\text { loam }\end{array}$ & $\begin{array}{l}\text { Sandy } \\
\text { clay loam }\end{array}$ & $\begin{array}{l}\text { Sandy } \\
\text { clay loam }\end{array}$ & $\begin{array}{l}\text { Sandy } \\
\text { clay } \\
\text { loam }\end{array}$ \\
\hline B.Density & $\mathrm{gcm}^{-3}$ & 1.29 & 1.45 & 1.55 & 1.65 & 1.7 & 1.75 \\
\hline SLL & $\mathrm{mmmm}^{-1}$ & 0.057 & 0.076 & 0.076 & 0.076 & 0.078 & 0.079 \\
\hline SDUL & $\mathrm{mmmm}^{-1}$ & 0.24 & 0.17 & 0.18 & 0.18 & 0.17 & 0.17 \\
\hline Saturated SW & $\mathrm{mmmm}^{-1}$ & 0.46 & 0.36 & 0.33 & 0.29 & 0.27 & 0.26 \\
\hline Soil Albedo & 0.14 & & & & & & \\
\hline
\end{tabular}




\subsection{Planting Windows}

The five planting windows (PW's) were designated as PW1 $\left(20^{\text {th }}\right.$ and $23^{\text {rd }}$ October at Islamabad and $16^{\text {th }}$ and $22^{\text {nd }}$ October at Chakwal), PW2 (Sowing on $26^{\text {th }}$ October and $5^{\text {th }}$ November at Islamabad while $25^{\text {th }}$ and $31^{\text {st }}$ October at Chakwal), PW3 (Sowing on $5^{\text {th }}$ and $19^{\text {th }}$ November at Islamabad while $6^{\text {th }}$ and $14^{\text {th }}$ November at Chakwal), PW4 (Sowing on $19^{\text {th }}$ and $27^{\text {th }}$ November at Islamabad while $15^{\text {th }}$ and $23^{\text {rd }}$ November at Chakwal) and PW5 (Sowing on $5^{\text {th }}$ and $10^{\text {th }}$ December at Islamabad while $4^{\text {th }}$ and $5^{\text {th }}$ December at Chakwal) during 2008-2009 (Environment One, E1) and 2009-2010 (Environment two, E2) respectively.

\section{Bucket size}

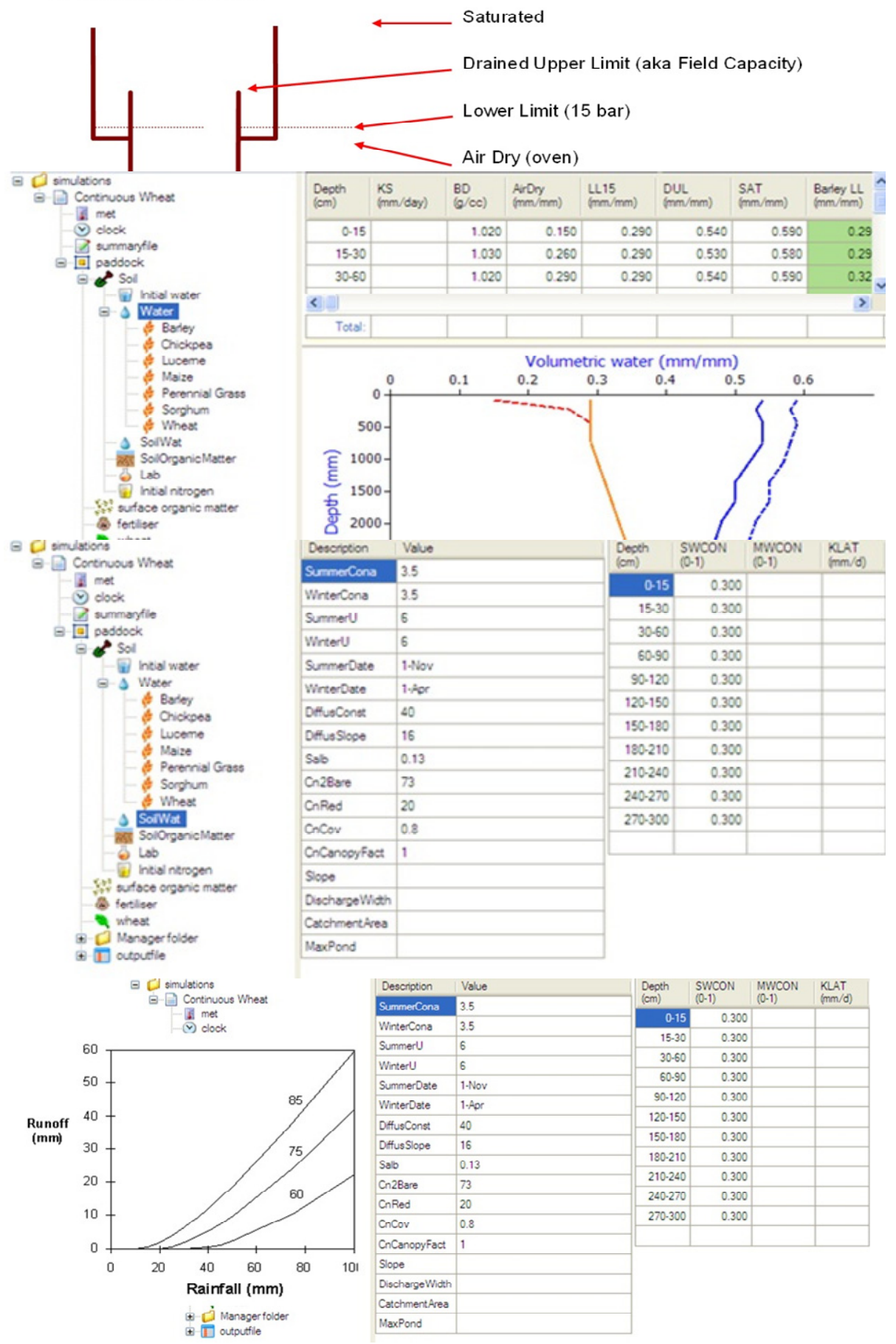

Figure 3. Working dynamics of soil water as described by APSRU (Source: http://www.apsim.info/Wiki/SoilWat.ashx) 


\subsection{APSIM Model}

APSIM Soil Water module is a flowing water balance model that has much from its ancestors model the CERES (Jones \& kiniry, 1986) and PERFECT (Littleboy et al., 1992). The procedures for redistribution of water throughout the soil profile have been inherited from CERES family models. The water characteristics of the soil are specified in terms of saturated (sat) volumetric water contents, drained upper limit and lower limit. The separate procedures define the water movement for saturated and unsaturated flow. Solutes such as nitrate- and urea-N redistribution have also been carried out in this model. The model is interfaced with the RESIDUE and the crop models so that the simulation of the soil water dynamics responds to the change in the status of the surface residues and crop cover. The working dynamics of APSIM as described by APSRU about soil water movement has been expressed diagrammatically in Figure 3 (APSIM, 2013).
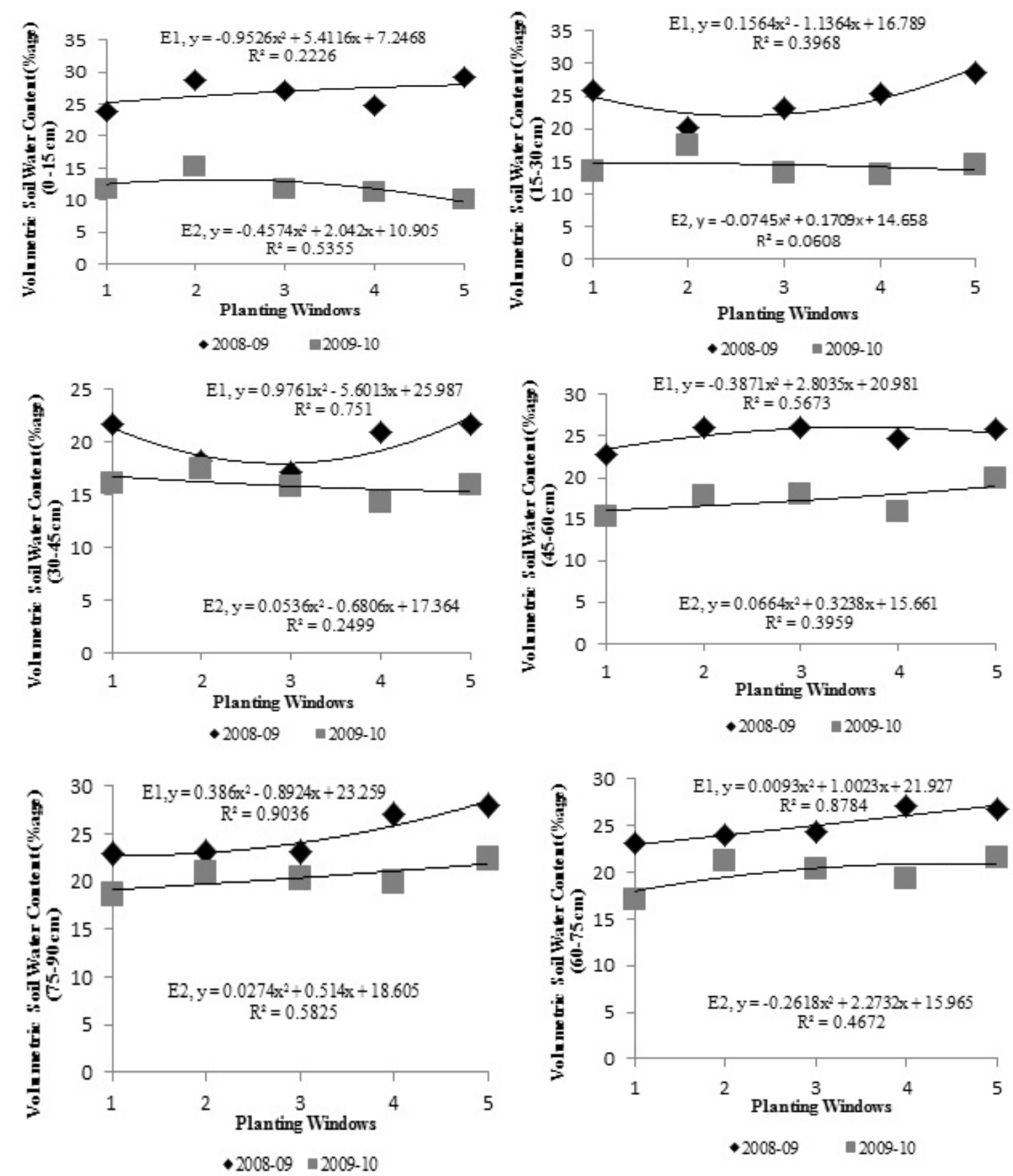

Figure 4. Volumetric soil water Content (\%) of wheat field at Islamabad among five planting windows (PW's) for six depths $(0-15,15-30,30-45,45-60,60-75 \& 75-90 \mathrm{~cm}$ respectively) at pre-sowing for two environments

$(\mathrm{E} 1=2008-09$ \& $\mathrm{E} 2=2009-10)$ 


\section{Results and Discussion}

Available soil water in the field before the sowing of a crop is the critical factor, which affect crop emergence and establishment to a considerable degree. Soil water availability during 2008-2009 at Islamabad was higher as compared to 2009-10 (Figure 5). Similarly, pre-sowing soil water among planting windows (PW's) at Islamabad for six depths during 2008-2009 and 2009-2010 have shown significant variability (Figure 5). The maximum soil water $(44.01 \mathrm{~mm}$ ) was recorded for PW5 for upper soils profile during 2008-2009, 66\% higher than soil water contents in the same soil profile for PW5 during 2009-2010. However, down the depth among all PW's, significant increase in soil water was recorded, that might be the result of higher seasonal rains during 2008-2009 compared to 2009-2010. Similarly, maximum plant available water contents (PAWC) during 2008-2009 remained higher in all layers compared to 2009-2010. Variability in soil water among two environments might be due to difference in rainfall. Rainfall occurrence has been a limiting factor and lead to drought which ultimately resulted to water reduction (Xie et al., 2003).
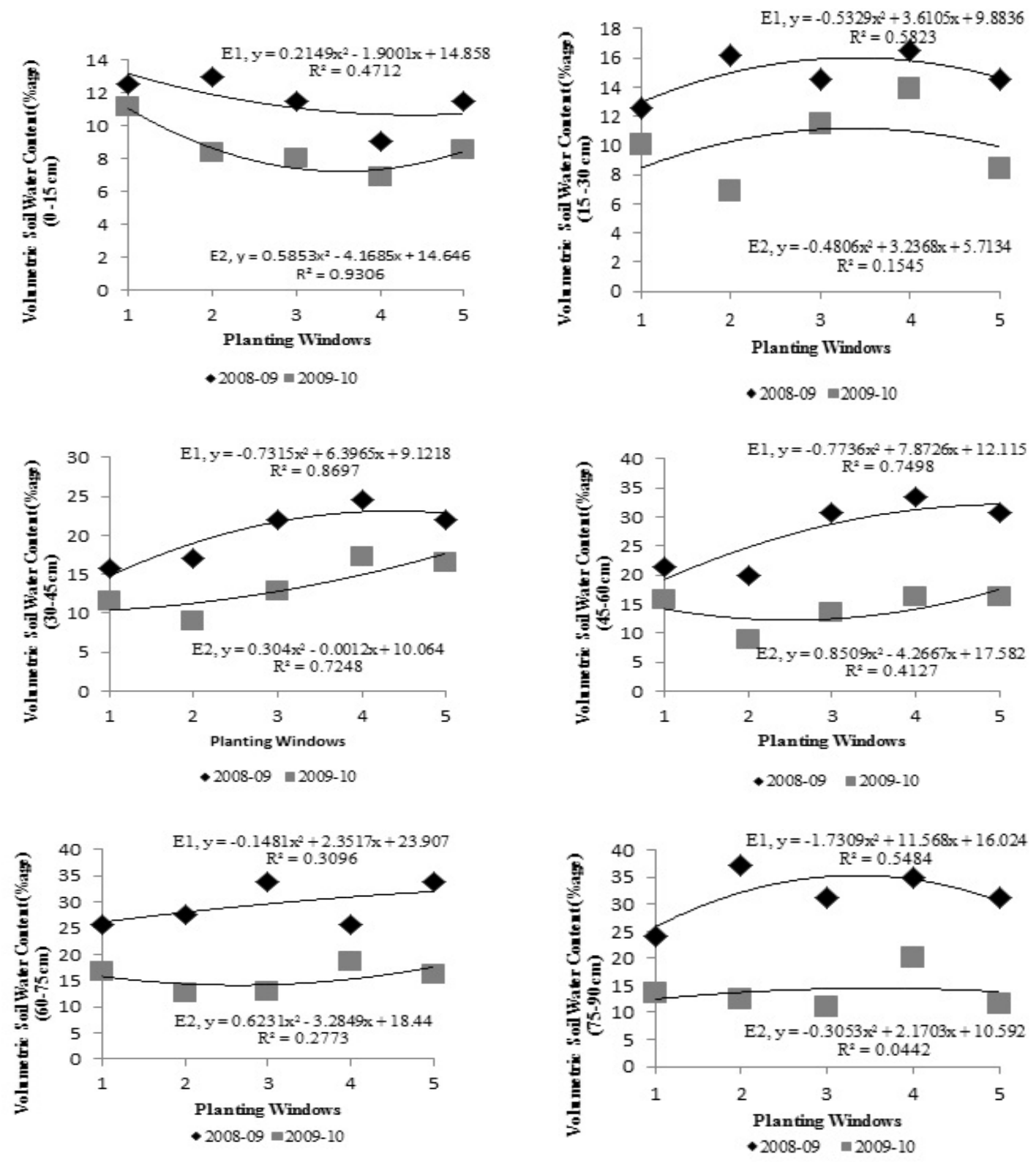

Figure 5. Volumetric soil water Content (\%age) of wheat field at Chakwal among five planting windows (PW's) for six depths $(0-15,15-30,30-45,45-60,60-75 \& 75-90 \mathrm{~cm}$ respectively) at pre-sowing for two environments $(\mathrm{E} 1=2008-09 \& \mathrm{E} 2=2009-10)$ 
Pre-sowing soil water content at Chakwal depicted significant differences among environments (2008-2009 and 2009-2010), planting windows (PW's) and depths (Figure 6). The results depicted the presence of higher soil water among environments during 2008-09 compared to 2009-10. Similarly, soil water content remained higher among planting windows during 2008-2009 as compared to 2009-2010. Soil water contents in the upper soil profile in PW's revealed that it remained higher in PW2 $(19.53 \mathrm{~mm})$ followed by PW1 (18.84 mm), PW3 (17.21 mm), PW5 $(17.21 \mathrm{~mm})$ and PW4 $(13.62 \mathrm{~mm})$ during 2008-09. Soil profiling at $15-30 \mathrm{~cm}$ showed maximum soil water in PW4 $(24.77 \mathrm{~mm})$ and minimum noted in PW1 $(18.91 \mathrm{~mm})$. However, down the depth in all PW's, a significant increase of soil water content was visible during 2008-09. The total soil water (sum of soil water in all soil profiles, 15-90 $\mathrm{cm}$ ) during 2008-09, remained higher in PW4 $(216.15 \mathrm{~mm}$ ) while lesser total soil water was noted in PW1 (167.59 $\mathrm{mm})$. However, during 2009-10, maximum water in upper soil profile was recorded in PW1 (16.67mm) while minimum noted in PW4 (10.28mm). The down the depth significant increase in soil water recorded with significant high value of $\mathrm{R}^{2}$. Therefore, model developed based on collected soil water data could be used accurately to measure soil water dynamics for the future cropping systems.

Rainfall is the only source of irrigation in most arid regions of Pakistan. Rainfall distribution plays an important role in the soil water dynamics. In arid areas of Pakistan, rainfall pattern is variable and most of the rain occurs in monsoon season. This rain is much beneficial for the upcoming crop, sown in early winter season. Islamabad received more rainfall while Talagang received less. The trend of rainfall distribution is illustrated in Figure 6; this trend of rainfall variability was in accordance with Liu and Yanai (2001); Lau and Nath (2000). Similarly, distribution of rain water into soil is given in Figure 6. Saturated soil water contents based on bulk density of soil revealed maximum value at top soil profiles, it decreased down the depth at all locations. Saturation percentage and total porosity decreased for deeper layers while drain upper layer and volumetric water contents increased down the depth. Our results are in accordance with previous reports, in which the authors have suggested that soil water has a capricious influence under different soil environments such as different catchments (Fu et al., 2000, 2003), bench terraces (Sang-Arun et al., 2005), groundnut fields (Gardner \& Gerard, 2003).

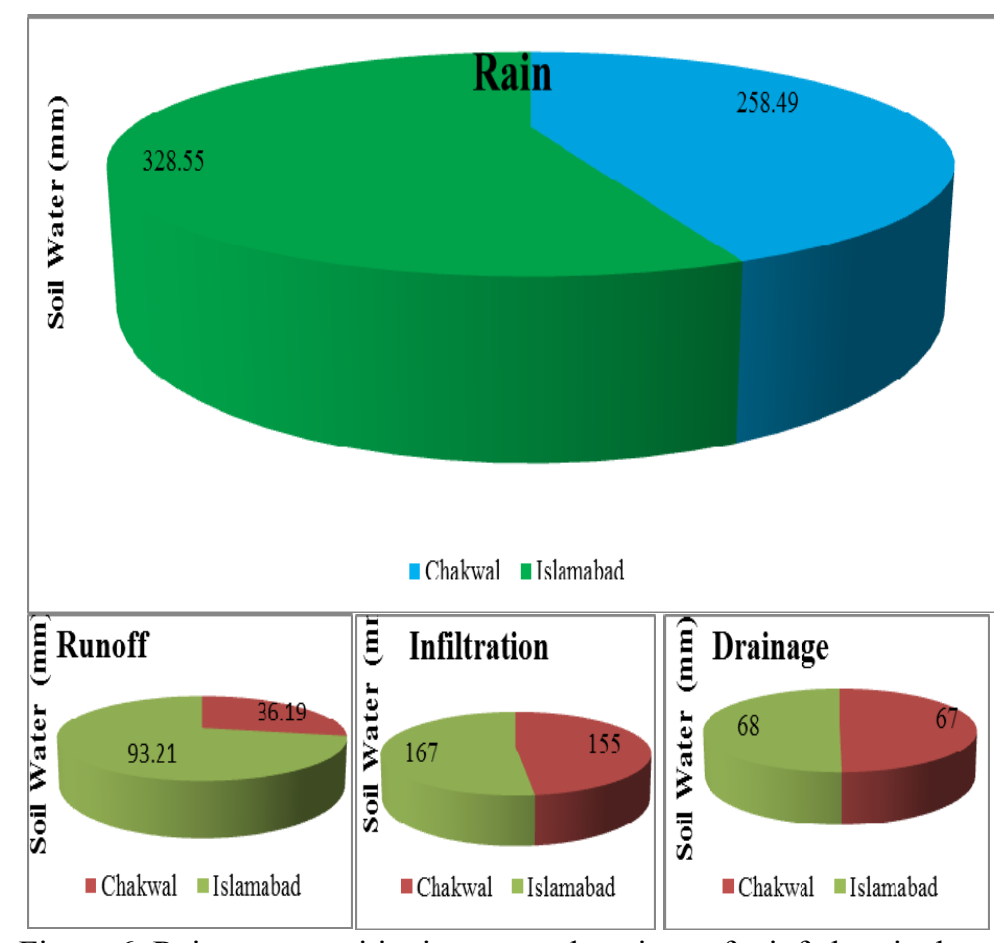

Figure 6. Rainwater partitioning at two locations of rainfed agriculture

APSIM Soil Water module was used to simulate soil water in rainfed areas. Model simulated soil water in the form of infiltration, drainage and runoff. Soil water dynamics is the totality of infiltration, runoff and drainage. The infiltration rate defines the amount of water that is infiltrated into the ground. Soil permeability and flow conditions particularly limit the amount of rainwater that can be soaked up by the ground. Moreover, infiltration depends on the texture of the soil. With the increase in rainfall, infiltration increases significantly (Figure 6). The 
relationship between observed and predicted values of infiltration is illustrated in Figure 7. At Chakwal, high value of infiltration (167 and $155 \mathrm{~mm}$ ) was calculated while, at Islamabad low value of infiltration (58 mm) was depicted (Figure 7). Infiltration was higher than runoff and drainage (Figure 7). To simulate infiltration, regression equation was developed as Infiltration $=8.19628+0.514212 \mathrm{x}$ Rain. Rain is the main driving force for soil water dynamics.
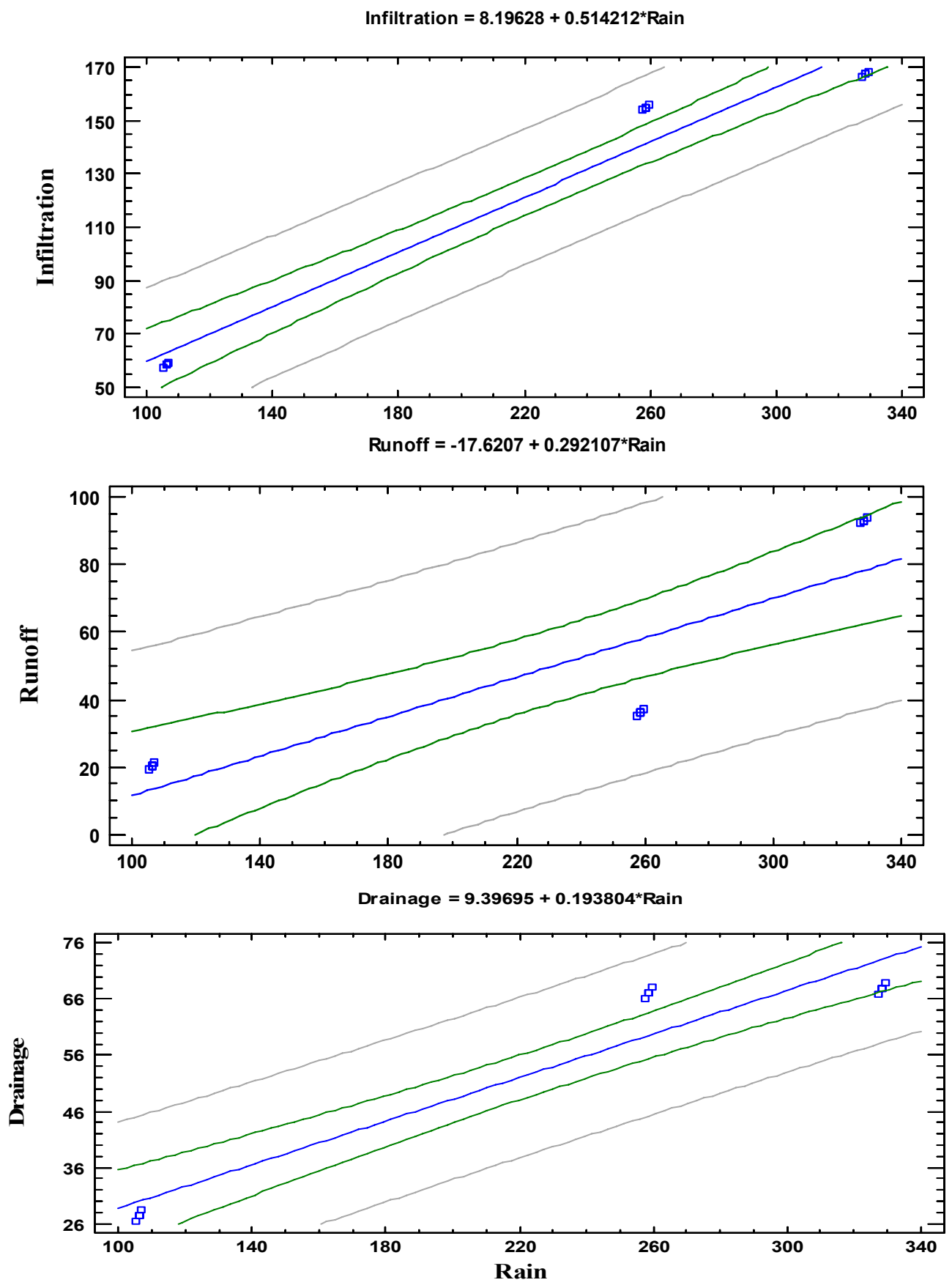

Figure 7. Relationship of rainwater with infiltration, drainage and runoff

Runoff is reliant on the geography and wetness of the soil. High value of runoff was calculated at Islamabad (93 $\mathrm{mm})$. At Islamabad, the soil had more slope as compared to other location so more runoff was observed. Runoff cure (Figure 7) developed by model (Runoff $=-17.6207+0.292107$ x Rain) and results were confirmed by $1: 1$ line to simulate runoff. Drainage occurs only when soil water contents were between drain upper limit and saturation point. At Islamabad and Chakwal, more drainage $(67 \mathrm{~mm})$ observed in our study (Figure 7). Drainage is 
significantly related to rain which can be highlighted by the equation, Drainage $=9.39695+0.193804 \times$ Rain. In rainfed regions, rain is the only factor of water availability for the standing crops. Hence, rainfall distribution into different components could be simulated by the use of APSIM model (Figure 7). Similarly, soil water dynamics have been simulated in these areas by regression model (Rain $=13.5928+2.28626 \mathrm{x}$ Infiltration $+0.749315 \mathrm{x}$ Runoff - $2.03557 \mathrm{x}$ Drainage). This model showed clearly how rain water is distributed in the soil in different forms. By this model we can predict distribution of rainwater in the soil.

The observed and predicted values of soil water dynamics revealed that pre-sowing soil water $(\mathrm{mm})$ in this study varied from 40 to $50 \mathrm{~mm}$ in loam and sandy clay soil of Islamabad and Chakwal, respectively. The dynamics of soil water from emergence to maturity vary, during earlier growth stages it remains at highest level, when the crop roots are established and utilized soil water effectively, soil water begins to decline. The soil dynamics reached to the lowest level at maturity which may be due to evapotranspiration (Figure 8). The variability in soil water reported in earlier studies have been related to extreme climatic events. Therefore, using models and making relationship of soil features with climatic drivers, the issue of food security can be tackled to some extent under rainfed agriculture. The crop production in rainfed regions depends on precipitation, therefore, the storage efficiency (PSE) and buffering influence of water stored in the soil profile could be used to sustain crops and stored soil water in different locations can be effectively utilized. The occurrence of rainfall and availability of soil water for crops is highly variable and it needs to be managed by matching crop cultivars with prevailing weather conditions or by adapting suitable management practices such as shift in sowing times. Water use by the crop at specific stage depends on its evaporative demands and crop coefficient at a particular stage and these two values can be taken from Food and Agriculture Organization (FAO) manual. Therefore, by multiplying evaporative demand and crop coefficient, water use at specific stage can be determined. However, available soil water below $50 \%$ leads standing crops to moderate to high stress, so it is very important to manage soil water dynamics using models to provide an escape to crops against stresses.

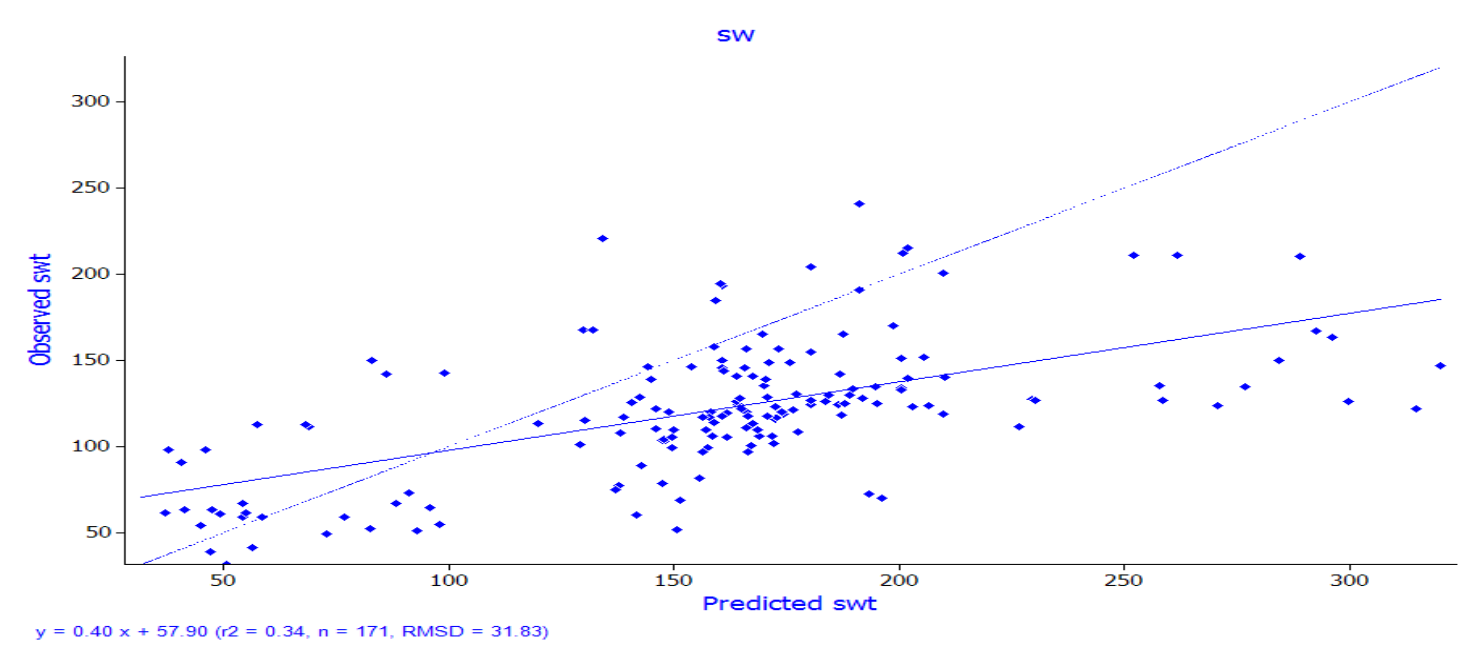

Figure 8. Observed and simulated soil water dynamics for rainfed agriculture at Islamabad (swt $=$ total soil water in $\mathrm{mm})$

\section{Conclusion}

The result of present study depicted that models could be used as management tools to simulate soil water dynamics and to minimize climate related risks to rainfed agriculture. Therefore, models information under different scenario needs to be incorporated to boost agricultural productivity under changing climatic conditions. The validation skill scores like $\mathrm{R}^{2}$ confirmed the model performance, therefore, dynamic model like Agricultural Production System Simulator (APSIM) could be used to describe the distribution of rainwater into different components like infiltration, runoff and drainage, and it can be used as a decision support tool for accurate management of different cultural operations for sustainable atmosphere-soil-plant (ASP) system. 


\section{References}

Agricultural Production Systems Simulator (APSIM). (2013). Retrieved 4 September 2012, from http://www.apsim.info/Wiki/SoilWat.ashx

Ahmed, M. (2010). ENSO cycle effects on rainfed wheat of Pakistan. Paper read at ASA,CSSA, and SSSA 2010 International Annual Meetings, at Long Beach, Convention Centre USA.

Ahmed, M., Hassen, F., \& Aslem, M. (2010). Climatic resilience of wheat comparing modeled and observed crop yields in Pothwar/East Pakistan. The International J of Climate Change., 2(2), 32-48.

Akhtar, M. S., \& Qureshi, S. (1996). Soil physics program. Annual Report, 1994-1995 (pp. 1-68). Land Resource Research Institute, National Agricultural Research Center, PARC. Islamabad.

Ali, M. S., Mahmood, S., Chaudhary, M. N., \& Sadiq, M. (2009). Irrigation quality of ground water of twenty villages in Lahore district. Soil Environ., 28(1), 17-23.

Dettori, M., Cesaraccio, C., Motroni, A., Spano, D., \& Duce, P. (2011). Using CERES-Wheat to simulate durum wheat production and phenology in Southern Sardinia, Italy. Field Crops Res., 120(1), 179-188. http://dx.doi.org/10.1016/j.fcr.2010.09.008

Economic Survey of Pakistan. (2011). Economic adviser's wing, finance division, Government of Pakistan, Islamabad.

Falkenmark, M. (2003). Freshwater as shared between society and ecosystems: from divided approaches to integrated challenges. Philos Trans $R$ Soc Lond B Biol Sci., 358(1440), 2037-49. http://dx.doi.org/10.1098/rstb.2003.1386

Farooqi, A. B., Khan, A. H., \& Mir, H. (2005). Climate change perspective in Pakistan. Pak J Meteor., 2(3), 11-21.

Frigg, R., \& Hartmann, S. (2006). Models in science. In E. D. Zalta (Ed.), The Stanford Encyclopedia Of Philosophy. Stanford.

Fu, B. J., Chen, L. D., Ma, K. M., Zhou, H. F., \& Wang, J. (2000). The relationship between land use and soil conditions in the hilly areas of the Loess Plateau in northern Shaanxi, China. Catena., 36, 69-78. http://dx.doi.org/10.1016/S0341-8162(03)00065-1

Fu, B., Wang, J., Chen, L., \& Qui, Y. (2003). The effects of land use on soil water variation in the Danangou catchment of the Loess Plateau, China. Catena, 54, 197-213.

Gardner, R. A. M., \& Gerrard, A. J. (2003). Runoff and soil erosion on cultivated rainfed terraces in the Middle Hills of Nepal. Applied Geography., 23, 23-45.

Jones, C. A., \& Kiniry, J. R. (1986). CERES-Maize A simulation model of maize growth and development. College Station, Texas: Texas A\&M University Press.

Lau, N. C., \& Nath, M. (2000). Impact of ENSO on the variability of the Asian-Australian monsoons as simulated $\begin{array}{llllll}\text { in } \mathrm{GCM} & \text { experiments. } & J & \text { Climate., } & 13, & \text { 4287-4309. }\end{array}$ http://dx.doi.org/10.1175/1520-0442(2000)013<4287:IOEOTV >2.0.CO;2

Liang, W. L., Kosugi, K., \& Mizuyama, T. (2007). Heterogeneous soil water dynamics around a tree growing on a steep hillslope. Vadose Zone J., 6(4), 879-889. http://dx.doi.org/10.2136/vzj2007.0029

Littleboy, M., Silburn, D. M., Freebairn, D. M., Woodruff, D. R., Hammer, G. L., \& Leslie, J. K. (1992). Impact of soil erosion on production in cropping systems. I. Development and validation of a simulation model. Aust $J$ Soil Res., 30, 757-774. http://dx.doi.org/10.1071/SR9920757

Liu, X., \& Yanai, M. (2001). Relationship between the Indian Monsoon Rainfall and the Tropospheric Temperature Over the Eurasian Continent. Quart J. Roy Meteor Soc., 127, 909-938. http://dx.doi.org/10.1002/qj.49712757311

Longobardi, A., Villani, P., Grayson, R. B., \& Western, A. W. (2003). On the relationship between runoff coefficient and catchment initial conditions, in: Proceedings of MODSIM 2003 International Congress on Modelling and Simulation, Townsville, Australia, 14-17 July 2003. Modelling and Simulation Society of Australia and New Zealand Inc., 2, 867-872.

McCown, R. L., Hammer, G. L., Hargreaves, J. N. G., Holzworth, D. P., \& Freebairn, D. M. (1996). APSIM: A novel software system for model development, model testing, and simulation in agricultural systems research Agric. Systems, 50, 255-271. http://dx.doi.org/10.1016/0308-521X(94)00055-V 
Meehl, G. A., \& Tebaldi, C. (2004). More intense, more frequent, and longer lasting heat waves in the 21 st century. Science., 305, 994-997. http://dx.doi.org/10.1126/science.1098704

Ritchie, J. (1981). Water dynamics in the soil-plant-atmosphere system. Plant and Soil., 58, 81-96. http://dx.doi.org/10.1007/BF02180050

Sang-Arun, J., Mihara, M., Horaguchi, Y., \& Yamaji, E. (2005). Soil erosion and participatory remediation strategy for bench terraces in northern Thailand. Catena., 65, 258-264. http://dx.doi.org/10.1016/j.catena.2005.11.010

Schar, C., Vidale, P. L., Lu, D., Frei, C., Haberli, C., Mark, A., Liniger, M. A., \& Appenzeller, C. (2004). The role of increasing temperature variability in European summer heatwaves. Nature., 427, 332-336. http://dx.doi.org/10.1038/nature02300

Stone, R., \& Auliciems, A. (1992). SOI phase relationships with rainfall in eastern Australia. Intl J Climatol., 12, 625-36. http://dx.doi.org/10.1002/joc.3370120608

Wainwright, J., \& Parsons, A. J. (2002). The effect of temporal variation in rainfall on scale dependency in runoff coefficient. Water Resources Research., 34(7), 1755-1766.

Wang, E., Robertson, M. J., Hammer, G. L., Carberry, P. S., Holzworth, D., Meinke, H., ... McLean, G. (2002). Development of a generic crop model template in the cropping system model APSIM. Eur. J. Agron., 18(1-2), 121-140. http://dx.doi.org/10.1016/S1161-0301(02)00100-4

Xie, A., Sun, Y. G., \& Bai, R. H. (2003). Arid climate trend over Northeastern China and its response to global warming. Acta Geograph Sin., 58, 75-82.

Yamaguchi, Y., \& Shinoda, M. (2002). Soil moisture modelling based on multiyear observations in the Sahel. $J$. $\begin{array}{lll}\text { Appl. } & \text { Meteorol., } & \text { 1140-1146. }\end{array}$ http://dx.doi.org/10.1175/1520-0450(2002)041<1140:SMMBOM>2.0.CO;2 